J. Clin. Chem. Clin. Biochem.

Vol. 19, 1981, pp. 283-286

\title{
Hepatotoxic Effects of Sera from Patients with Fulminant Hepatitis B on Isolated Rat Hepatocytes in Culture
}

\author{
By Th. Haas, C. J. Holloway, Vera Osterthun and I. Trautschold \\ Institute of Clinical Biochemistry, Medical School, Hannover
}

(Reccived July 17, 1980/January 5, 1981)

Summary: The hepatotoxicity of sera from patients with terminal fulminant hepatic failure has been investigated by cell culture techniques. It could be shown that both untreated and heat-treated sera are cytotoxic in nature. Com. pared with the action of sera from heal thy individuals on liver cells in primary monolayer culture, the pathological sera exhibited significantly different behaviour with respect to morphological and biochemical parameters such as cell adhesion, growth and proliferation, and enzyme release.

\section{Hepatotoxische Wirkung von Seren von Patienten mit fulminanter Hepatitis B auf isolierte Hepatocyten in Kultur}

Zusammenfassung: Seren von Patienten mit akutem Leberversagen nach Hepatitis B wurden mit Hilfe von Zellkulturtechniken hinsichtlich ihrer Hepatotoxizität untersucht. Es konnte gezeigt werden, daß sowohl unbehandelte als auch hitze-behandelte Seren cy totoxisch wirken. Verglichen mit Normalseren beeinflussen pathologische Seren in erheblich stärkerem Maße das morphologische und biochemische Verhal ten der Leberzellen in Kultur, wie Zell-Adhäsion, Wachstum und Zellteilung und Enzymaustritt.

\section{Introduction}

Although diagnostic and therapeutic techniques for liver disease have advanced rapidly in recent years, many important questions remain unanswered in this field. In particular, our knowledge concerning the mechanism of necrosis in fulminant liver failure and the accompanying endogenous toxicological problems is far from complete. However, it is known that several agents such as phenolic compounds (1), ammonia, fatty acids, bile acids, and mercaptans (2) for example are present in dramatically increased amounts in the serum of patients in liver coma. It is believed that many patients with acute hepatic failure could be saved if some artificial device were available for the effective removal of these toxins from the blood during the acute phase of the disease (3). In order to gain more information on the mechanism of this cytotoxicity, and to establish a model for evaluating detoxification procedures, we have applied the techniques of cell culture. Our initial experiments have been carried out with sera from patients with terminal fulminant liver failure following acute viral hepatitis $B$, to decide whe ther isolated hepatocy tes in cul ture can serve as a reliable monitor for the action of endogenous toxins.

\section{Material and Methods}

Liver cells were isolated from neonatal rats (Han:Wistar) by stepwise enzymatic digestion with Dispase II (Boehringer Mannheim), according to a method modified from Takaoka et al. (4). The tissue was minced with scalpels and washed in phosphatebuffered saline without $\mathrm{Ca}^{++}$and $\mathrm{Mg}^{++}$. After shaking for $15 \mathrm{~min}$ at $37^{\circ} \mathrm{C}$ in phosphate-buffered saline without $\mathrm{Ca}^{2+}$ and $\mathrm{Mg}^{2+}$, tissues were incubated three times for $15 \mathrm{~min}$ at $37^{\circ} \mathrm{C}$ in a reciprocal shaker (GFL 1083) with Dispase II $(1.8 \mathrm{kU} / \mathrm{l})$ in a modified Eagle's minimal essential medium supplemented with $10 \times 10^{-2}$ foetal calf serum, followed by pipetting. Cell suspensions were centrifuged for $2 \mathrm{~min}$ at $300 \mathrm{~g}$, the supernatant fluid was discarded, and the sedimented cells were resuspended in a medium of the same composition as described above. The final cell suspensions were filtered through a V2A sieve, and diluted to a cell inoculum size of about $2 \times 10^{9} / 1$. The cells were seeded into Petri dishes ( $6 \mathrm{~cm}$ diameter; NUNC, Denmark), and cultured at $37^{\circ} \mathrm{C}$ at $5 \times 10^{-2} \mathrm{CO}_{2}$ and water vapour-saturated atmosphere. The culture medium was changed every 48 hours. Confluent cell sheets of mixed population - epithelial and non-epithelial cells were obtained under these conditions after 4 to 6 days in culture. All the procedures described were carried out under sterile conditions.

The viability of cells in culture was investigated by Trypan blue exclusion tests and by $\left[{ }^{14} \mathrm{C}\right.$ leucine and $\left[{ }^{14} \mathrm{C}\right.$ thymidine incorporation into cellular proteins and DNA respectively, as judged by the radioactivity of trichlornacetic acid precipitates.

In order to study the action of sera from comatose patients on hepatocytes, cell shects werc incubated in culture medium con- 
taining an additional $20 \times 10^{-2}$ of sera from healthy individuals, and sera from patients with fulminant hepatic failure following acute viral hepatitis $B$, respectively. At the time of sampling the patients were in hepatic coma of grade III-IV.

There were two basic experimental groups:

1) Cells were incubated in culture medium containing normal or coma sera for $96 \mathrm{~h}$.

2) Cells were incubated in culture medium containing normal or coma sera as above, but the sera were heat-treated at $60^{\circ} \mathrm{C}$ for $30 \mathrm{~min}$ prior to use. In one group of cultures, the medium containing coma serum was substituted by control medium after

$24 \mathrm{~h}$, and incubated for a further $48 \mathrm{~h}$. Total incubation time in this case was thus $72 \mathrm{~h}$.

All sera used were passed through a $0.45 \mu \mathrm{m}$ Millipore filter.

After incubation, the following parameters were investigated:

- morphology by phase-contrast microscopy,

- DNA content by a fluorometric assay modified from that of Hesse et al. (5).

- total protein by a method modified by Oyama et al. (6) and based on the Lowry method, and

- activities of glutamate dehydrogenase (EC 1.4.1.3), aspartate aminotransferase (EC 2.6.1.1), and alanine aminotransferase (EC 2.6.1.2) in cells and culture medium. The enzýme assays were carried out at $25^{\circ} \mathrm{C}$ using optimised commercial test kits (Boehringer Mannheim).

Culture medium was aspirated and stored for estimation of enzyme activities; the monolayers were washed twice with phosphate-buffered saline without $\mathrm{Ca}^{++}$and $\mathrm{Mg}^{++}$, then the cells were dispersed from the anchorage with a rubber policeman, homogenised by an Ultra Turrax (Janke \& Kunkel GmbH, Type T 18/10, $20000 \mathrm{rpm}, 30 \mathrm{~s}$ ), and DNA und protein contents as well as enzyme activities were measured in homogenates.

\section{Results}

The cultures subjected to coma serum, as compared with those in normal medium, morphologically showed a higher degree of detachment of cells from the anchorage, and the cell sheet no longer constituted a confluent monolayer. This effect is also reflected in the DNA and total protein contents of the monolayers, and in the enzyme activities, which can be seen in the significant decrease of these parameters as depicted in table 1.

Not only does the total activity on a plate decrease as a result of the action of coma serum, but also the specific activities of the monolayers are lower than in the controls. Furthermore, the activities of enzymes measured in the culture medium increase when coma serum is present, and are related not only to the DNA content (fig. 1), but also to total protein content of the respective monolayer.

Heat-inactivated sera from patients with fulminant liver failure were not found to diminish proliferation or growth of the cells in monolayer cultures. However, the cells
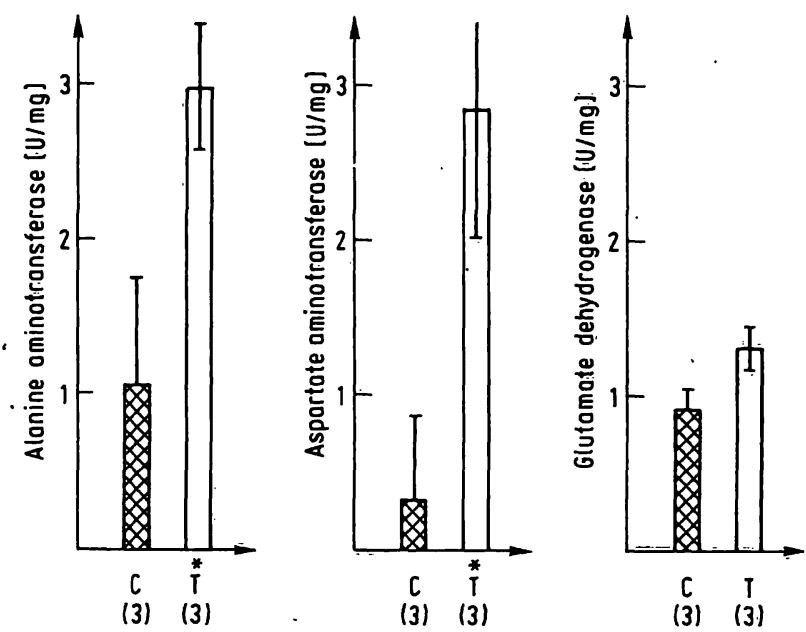

Fig. 1. Enzyme activities of alanine aminotransferase, aspartate aminotransferase, and glutamate dehydrogenase in the culture medium related to the DNA contents of the respective monolayers after an incubation period of $96 \mathrm{~h}$. $\mathrm{C}=$ "controls", culture medium plus normal serum $\left(20 \times 10^{-2}\right)$.

$T=$ "toxic samples", culture medium plus coma serum $\left(20 \times 10^{-2}\right)$.

All values are corrected for basal enżyme activities as measured in the medium after $96 \mathrm{~h}$ at $37^{\circ} \mathrm{C}$, in air with $5 \times 10^{-2} \mathrm{CO}_{2}$ and water vapour-saturated atmosphere without cells. Values are given as means \pm standard deviations; toxic values are compared with the controls by Student's t-test (18).

Probabilities of significance are represented by:

$*=p \leqslant 0.025$

$* *=\mathrm{p} \leqslant 0.005$

$* * *=p \leqslant 0.0005$

The number of measurements is given in parentheses.

Tab. 1. DNA contents of monolayers together with total enzyme activities of the monolayers.

Values are given as mean \pm standard deviation; the number $\mathrm{n}$ of experiments is written in parentheses; "toxic samples" are compared with the controls; $p=$ probabilities of significance by Student's t-test (18).

\begin{tabular}{|c|c|c|c|c|c|}
\hline Culture & $\begin{array}{l}\text { DNA } \\
(\mu \mathrm{g} / \text { plate })\end{array}$ & $\cdots$ & $\begin{array}{l}\text { Alanine } \\
\text { aminotransferase } \\
\text { (mU/plate) }\end{array}$ & $\begin{array}{l}\text { Aspartate } \\
\text { aminotransferase } \\
\text { (mU/plate) }\end{array}$ & $\begin{array}{l}\text { Glutamate } \\
\text { dehydrogenase } \\
\text { (mU/plate) }\end{array}$ \\
\hline \multirow[t]{2}{*}{$\begin{array}{l}\text { Before incubation }{ }^{1} \text { ) } \\
\text { Control incubation }{ }^{2} \text { ) } \\
\text { "Toxic samples"3) }\end{array}$} & $\begin{array}{r}3.12 \pm 0.32(3) \\
19.24 \pm 2.28(3) \\
11.96 \pm 1.44(3)\end{array}$ & & $\begin{array}{l}5.00 \pm 0.96(3) \\
9.38 \pm 0.86(3) \\
5.70 \pm 0.90(3)\end{array}$ & $\begin{array}{l}14.18 \pm 1.04 \text { (3) } \\
25.00 \pm 4.4 \quad(3) \\
15.82 \pm 4.2 \quad(3)\end{array}$ & $\begin{array}{l}4.92 \pm 0.82(3) \\
39.2 \pm 4.4 \quad(3) \\
25.6 \pm 4.0\end{array}$ \\
\hline & p 0.005 & & p 0.005 & p $0: 05$ & $\mathrm{p} 0.01$ \\
\hline
\end{tabular}

1) Monolayers cultured in culture medium (modified Eagle's minimal essential medium supplemented with $10 \times 10^{-2}$ calf serum) before incubation for controls or toxic samples.

${ }^{2}$ ) "Controls", cultured in culture medium plus normal serum, $20 \times 10^{-2}$, after incubation for $96 \mathrm{~h}$.

3) "Toxic samples", cultured in culture medium plus coma serum, $20 \times 10^{-2}$, after incubation for $96 \mathrm{~h}$. 
were observed to be rich in vacuoles, and more cell debris was found in the medium. The enzyme activities in the cells related to DNA content of the cell sheet were decreased to a certain extent, but this result was not statistically significant. In contrast the activities of alanine aminotransferase and aspartate aminotransferase in the culture medium related to DNA (fig. 2) and also to total protein content of the respective monolayers were increased to a highly significant extent. Substitution of the toxic culture medium by a normal medium after $24 \mathrm{~h}$ exposure resulted, to a large extent, in normalisation, at least in the removal of toxic effects (fig. 2).

The ratio of intra- to extra-cellular enzyme activities also conforms to the effects described above, as seen in figure 3.

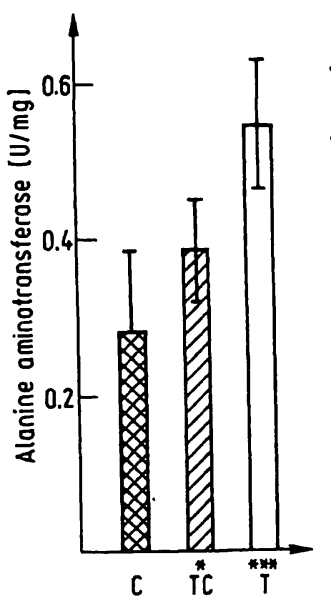

(9) (5) (9)

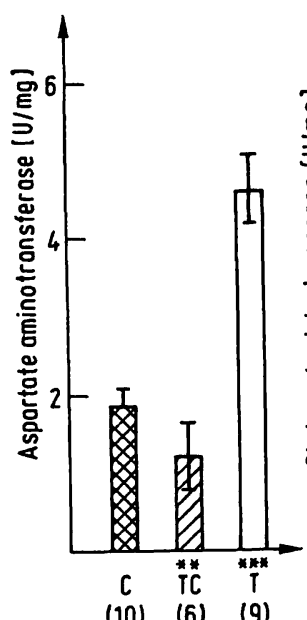

(10) (6) (9)

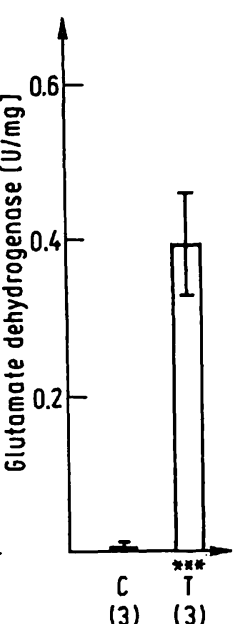

(3) (3)
Fig. 2. Enzyme activities of alanine aminotransferase, aspartate aminotransferase, and glutamate dehydrogenase in the culture medium related to the DNA contents of the respective monolayers after an incubation period of $72 \mathrm{~h}$ Normal as well as coma sera were heat-treated at $60^{\circ} \mathrm{C}$ for $30 \mathrm{~min}$ prior to use.

$C=$ "controls", culture medium plus normal serum $\left(20 \times 10^{-2}\right)$

$\mathrm{T}=$ "toxic samples", culture medium plus coma serum $\left(20 \times 10^{-2}\right)$

TC = cultured as "toxic samples" for the first $24 \mathrm{~h}$, the medium was then changed and cells were cultured in control medium for a further $48 \mathrm{~h}$.

Values are given as means \pm standard deviations; the mean values of $T$ and TC are compared with the controls. For representation of statistical significance see also legend of fig. 1.

\section{Discussion}

Hughes et al. $(7,8)$ have investigated the cytotoxicity of plasma from patients with fulminant hepatic failure towards isolated rabbit liver cells in vitro. Cytotoxicity was expressed as the mean loss of cells in test wells compared to control values. However, in their study, no measurement of a dynamic biochemical parameter was carried out. In our work, we have incubated cultures of isolated liver cells from neonatal rats with culture

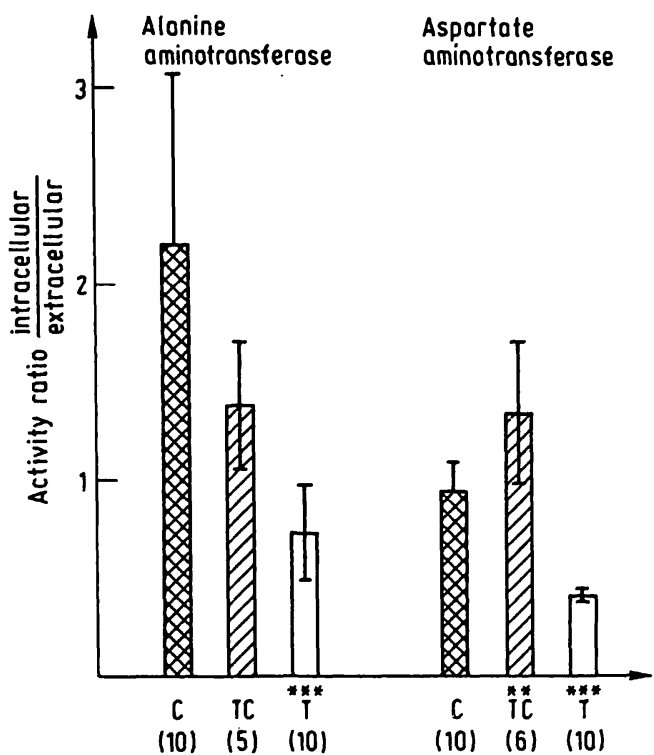

Fig. 3. Ratio of intracellular/extracellular enzyme activities after an incubation period of $72 \mathrm{~h}$.

For details see legend of fig. 2.

medium containing normal or comatose sera in order to examine whether such liver cell cultures could serve as a model for hepatotoxicity studies. The measurement of cell growth and proliferation, and the partition of enzymes between attached cells and culture medium provides quite a comprehensive picture of the effects of such "toxic" sera, and we have thus been able to demonstrate the destructive influence of sera from patients with acute liver failure towards such cell cultures.

It is difficult to explain "negative cytotoxicity" in a non-proliferating monolayer culture model as employed by Hughes et al. $(7,8)$. More detailed information on cytotoxic effects can be obtained by observing dynamic behavior of cultures.

Our experiments demonstrate that growth and proliferation of cultures are optimised by higher serum content of the culture medium (9). According to this finding, the addition of $20 \times 10^{-2}$ serum to the culture medium which itself already contains $10 \times 10^{-2}$ calf serum, leads to a strong increase of DNA content and total enzyme activities measured in the monolayers (see also table 1). The toxic serum diminishes this effect significantly by about 37 per cent. Furthermore the relatively high values for the DNA content and glutamate dehydrogenase activities of the cell sheets (table 1), as well as the small increase of glutamate dehydrogenase activity in the culture medium under toxic conditions, and related to DNA content of the respective monolayer (fig. 1), account for adsorptive interaction between the intact cells of the monolayers and cell debris and ghosts of mitochondria and other compartments of damaged cells.

Both untreated and heat-treated sera from comatose patients proved to be cytotoxic in nature, but the observed effects from the two types of sera were qualita- 
tively and quantitatively quite different. Whilst untreated sera led to a reduction in the amount of attached cells, compared with controls, proliferation and growth were not negatively influenced to any great extent by sera after heat treatment. Furthermore, in this case the enzyme release related to the DNA contents of the respective monolayers is smaller than in the first experimental group However, the large number of vacuoles observed here do indicate a toxic effect $(10,11)$.

Coma serum is known to contain several classes of welldefined small molecular-weight endogenous toxins such as phenolic compounds (1), fatty acids, ammonia, bile acids, and mercaptans (2), but our experiments also indicate the presence of some heat-labile cytotoxins which must be eliminated by heat treatment, and do not pass the filters used for sterilisation procedures. We believe that such toxins could be classified in the "endotoxin" (12) or "middle molecule" categories. In uraemia (13) and in normal rat plasma (14) heat-inactivable factors have been found which interfere with liver regeneration.

A massive increase in enzyme activities in the culture medium is caused by the action both of untreated or heat-treated coma serum. Measurements related to the DNA and total protein contents of the respective residual monolayers indicate a significant release of enzymes from damaged cells. This release occurs predominantly from cells which have detached from the

\section{References}

1. Hartmann, F. \& Ruger, W. (1962), Dtsch. Arch. Klin. Med. $208,298-322$.

2. Ziewe, L. \& Nicoloff, D. M. (1975), Am. Rev. Med. 26, 143-157.

3. Williams, R. (1976), Prog. Liver Dis. 5, 418-435.

4. Takaoka, T., Yasumoto, S. \& Katsuta, H. (1975), Japan. J. Exp. Med. 45, 317-326.

5. Hesse, G., Lindner, R. \& Krebs, D. (1975), Z. Allg. Mikrobiol. 15, 9-18.

6. Oyama, V. J. \& Eagle, H. (1956), Proc. Soc. Exp. Biol. Med. $31,305-307$.

7. Hughes, R., Cochrane, M. A. G., Thomson, A. D., MurrayLyon, I. M. \& Williams, R. (1975), in Artificial Liver Support (Williams, R. \& Murray-Lyon, I. M., eds.), Pitman Medical, London, pp. 263-268.

8. Hughes, R. D., Cochrane, M. A. G., Thomson, A. D., MurrayLyon, I. M. \& Williams, R. (1976), Br. J. Exp. Pathol. 57 , 348-353.

9. Griffiths, J. B. (1972), Exp. Cell Res. 75, 47-56

10. Swift, H. \& Hruban, Z. (1964), Fed. Proc. 23, 1026-1037. anchorage, since the enzyme activities of the cells remaining in the monolayer, again correlated with DNA and total protein content of the monolayer, are only slightly reduced.

The replacement of toxic culture medium by normal (control) medium after $24 \mathrm{~h}$ results in a reversal or at least no progression of the toxic effects and stabilisation of the culture with corresponding reduction of enzyme release. This observation is in accord with reversibility of acute liver failure by regeneration (15), and supports the strategy of artifical liver support by detoxification devices in order to accelerate the recovery processes (3).

Our experiments to date have demonstrated that liver cell cultures can serve as a sensitive model for hepatotoxic studies, both of a qualitative and a quantitative nature. Such a system may therefore prove useful as a monitor for the cytotoxicity of serum from patients wich liver failure, and for the assessment of therapeutic measures such as a temporary artificicial liver support system for the reduction of toxin levels in serum, as an alternative to the determination of toxic levels in such patients $(16,17)$.

\section{Acknowledgment}

The authors are grateful to the "Gesellschaft der Freunde der Medizinischen Hochschule Hannover" for their kind support for this project.
11. Trump, B. F. \& Ericsson, J. L. E. (1965), in The Inflammatory Process (Zweifach, B. W., Grant, L. \& McCluskey, R. T., eds.), Academic Press, New York \& London, pp. 35-110.

12. Liehr, H., Grün, M. \& Brunswig, D. (1976), Acta HepatoGastroenterol. 23, 235-240.

13. Chen, T. S. N. \& Leevy, C. M. (1973), Br. J. Exp. Pathol. S4, $591-596$.

14. Onda, H. \& Yoshikawa, J. (1973), Gann 64, 139-149.

15. Stöcker, E. \& Wullstein, H. K. (1975), in Liver Regeneration after Experimental Injury (Lesch, R. \& Reutter, W. eds.), Stratton Intercontinental Medical Book Corporation, New York, pp. 66-74.

16. Holloway, C. J., Brunner, G., Schmidt, E. \& Schmidt, F. W. (1979), Artif. Organs 3, 15-19.

17. Holloway, C. J., Brunner, G., Schmidt, E. \& Schmidt, F. W. (1980), in Hemperfusion: Kidney and Liver Supports and Detoxification (Sideman, S. \& Chang, T. M. S., eds.). Hemisphere Publishing Co., Washington, D. C., pp. 139-148.

18. Sachs, L. (1973), Angewandte Statistik, Planung und Auswertung, Methoden und Modelle, 4. erweiterte Aufl., Springer Verlag, Berlin, Heidelberg, New York, pp. 209-216.

Dipl.-Biochem. Theodor Haas Zentrum Biochemie Abteilung für Klinische Biochèmie Medizinische Hochschule Hannover Karl-Wiechert-Allee 9 D-3000 Hannover 61 